\title{
Clinico-Pathological Study to Evaluate Oral Lichen Planus for the Establishment of Clinical and Histopathological Diagnostic Criteria
}

\author{
Oral Liken Planusun Değerlendirilmesinde Geçerli Olan Klinik \\ ve Histopatolojik Tanısal Kriterlerin Saptanmasına Yönelik \\ Klinikopatolojik Çalışma
}

\author{
Santhosh KUMAR S HIREMATH' ${ }^{1}$, Alka D KALE², Seema HALLIKERIMATH² \\ Department of Oral Pathology, 'Babu Banarasidas College of Dental Sciences, LUCKNOW, INDIA, ${ }^{2}$ KLE-VK Institute of Dental Sciences, BELGAUM, INDIA
}

\begin{abstract}
Objective: Lichen planus and lichenoid lesions affecting the oral cavity show similar clinico-pathological features creating a diagnostic dilemma. Hence, the aim of the present study was to establish a clinical and histopathological correlation in the diagnosis of oral lichen planus, based on the modified WHO diagnostic criteria of oral lichen planus and oral lichenoid lesions proposed by Van der Meij and Van der Waal in 2003.
\end{abstract}

Material and Method: In the present study, 100 cases of oral lichen planus were clinically and histopathologically analyzed. Out of the 100 cases, 50 were prospective and 50 were retrospective cases. Prospective cases were collected based on the clinical diagnosis of oral lichen planus and oral lichenoid lesion. Retrospective cases were collected based on the histopathological diagnosis of oral lichen planus. Both the clinical and histopathological analyses were performed based on a proposal for a set of modified diagnostic criteria of oral lichen planus and oral lichenoid lesion. A final diagnosis of oral lichen planus was made only after the correlation of the clinical diagnosis with the histopathological diagnosis.

Results: The interobserver agreement among three observers for both prospective and retrospective cases in the final diagnosis of oral lichen planus was found to be "good" to "very good" indicating high reproducibility. However, the final diagnoses of true oral lichen planus after clinico-pathological correlation in prospective and retrospective study groups appeared to be $38.0 \%$ and $54.0 \%$ respectively.

Conclusion: The results of the present study revealed mild to moderate clinico-pathological correlation in the final diagnosis of oral lichen planus for the prospective and retrospective study groups respectively.

Key Words: Oral lichen planus, Mouth diseases, Reproducibility of findings

\section{ÖZ}

Amaç: Oral kaviteyi tutan liken planus ve likenoid lezyonlar, tanı zorluğu yaratan benzer klinikopatolojik özellikler gösterirler. Bundan dolayı, bu çalışmada 2003 yılında Van der Meij ve Van der Waal tarafından önerilen oral liken planus ve oral likenoid lezyonlarda modifiye WHO tanı kriterleri temel alınarak oral liken planus tanısında geçerli olacak klinik ve histopatolojik korelasyonu saptamak amaçlanmıştır.

Gereç ve Yöntem: Bu çalışmada, 50'si prospektif, 50'si retrospektif olmak üzere 100 oral liken planus olgusu klinik ve histopatolojik olarak değerlendirilmiştir. Prospektif olgular, oral liken planus ve oral likenoid lezyon klinik tanısına dayanarak toplanmıştır. Retrospektif olgular ise histopatolojik olarak oral liken planus tanısı almış olgulardan seçilmiştir. Olgular, oral liken planus ve likenoid lezyonlar için önerilen modifiye tanı kriterleri temel alınarak hem klinik hem histopatolojik olarak değerlendirilmiştir. Oral liken planus son tanısına, sadece klinik ve histopatolojik tanı korelasyonu elde edildikten sonra varılmıştır.

Bulgular: Son tanısı oral liken planus olan olgularda hem prospektif hem de retrospektif olgular için üç gözlemcinin gözlemciler arası görüş birliği, yüksek tekrarlanabilirliği işaret eden "iyi” ve "çok iyi" bulunmuştur. Yine de, prospektif ve retrospektif çalışma gruplarında klinikopatolojik korelasyon sonucunda gerçek oral liken planus son tanısı sırasıyla \%38.0 ve $\% 54.0$ olarak gözlenmiştir.

Sonuç: Sonuçlar, oral liken planus son tanısında klinikopatolojik korelasyonun prospektif çalışma grubunda hafif, retrospektif çalışma grubunda orta derecede olduğunu göstermiştir.

Anahtar Sözcükler: Oral liken planus, Ağız hastalıkları, Bulguların tekrarlanabilirliği
(Turk Patoloji Derg 2015, 31:24-29)

Received : 11.05.2014 Accepted : 09.09.2014
Correspondence: Santhosh Kumar S HIREMATH

Babu Banarasidas College of Dental Sciences, Department of Oral Pathology, LUCKNOW, INDIA

E-mail: santhosh_hiremath2007@rediffmail.com Phone: +91 9565356555 


\section{INTRODUCTION}

Oral Lichen Planus (OLP) is a chronic inflammatory disorder affecting the stratified squamous epithelium (1). The disease is relatively common, affecting approximately two percent of the total population and constitutes nine percent of all the white lesions of the oral cavity (2). Oral Lichen Planus can be present anywhere in the oral cavity and is almost invariably a bilateral disease on the buccal mucosa. Present trends classify OLP into three major clinical presentations as reticular, erosive/erythematous, and ulcerative (3).

Oral Lichen Planus and Oral Lichenoid lesions (OLL) pose a major diagnostic problem since their clinical and histopathological features overlap with each other. Distinguishing OLP and OLL from one another with only limited data may create a major diagnostic challenge, with considerable implications for patient management and follow up. Lichen Planus can be confused with other lichenoid conditions (such as Nonspecific Lichenoid Reactions, Atypical Lichenoid Stomatitis, Graft Versus Host Reactions [GVHRs], Drug Reactions, Lupus Erythematosus [LE], Erythema Multiforme [EM], and Oral Lichenoid Dysplasia [OLD]) both clinically and histopathologically. Hence it is important to familiarize oneself with the clinicopathological patterns of OLP and OLL, so as to develop an accurate diagnostic and prognostic assessment (4).

In 1978, the World Health Organization (WHO) centre for the study of precancerous lesions established a clinical and histopathological definition for the diagnosis of true OLP (Table I) (5). Ever since, this definition has been used in the diagnosis of OLP and regarded as 'gold standard' in the inclusion of patients in studies focusing on several aspects of OLP, but validation of this definition has never been performed (6). Clinical and histopathological assessment of OLP based on this WHO definition is rather subjective and insufficiently reproducible. Hence, it requires a proposed set of modified diagnostic criteria of OLP and OLL, based on the WHO definition of clinical and histopathological features (Table II) (6-8).

Oral Lichen Planus is a syndrome diagnosis that is based on the presence of several clinical and histopathological criteria. Thus, the diagnostic approach is best described as a method of pattern recognition both clinically and histopathologically (7). This indicates that diagnosis cannot be achieved solely based on the clinical or histopathological diagnosis. Confirmation of the diagnosis of OLP therefore has to be made after the correlation of the clinical and histopathological diagnoses. However, few data exist on the correlation between clinical and histopathological diagnoses of OLP.

The aim of the present study was therefore to establish a clinical and histopathological correlation in the diagnosis of OLP, based on the modified WHO diagnostic criteria of OLP and OLL.

\section{MATERIALS and METHODS}

In the present study, 100 cases were clinically and histopathologically analyzed. Out of 100 cases, 50 were prospective [mean $( \pm \mathrm{SD})$ age: $41.32 \pm 14.56$ years, minmax: $14-70$ years, males $=35(70.0 \%)$ and females $=15$ $(30.0 \%)]$ and 50 were retrospective [mean $( \pm S D)$ age: 39.64 \pm 15.20 years, min-max: $19-69$ years; males $=36(72.0 \%)$ and females $=14(28.0 \%)]$ cases.

For the selection of the prospective cases, three different clinicians participated. All the clinicians were well trained and experienced. Out of 50 prospective cases, 40 cases

Table I: World Health Organization diagnostic criteria (1978) of oral lichen planus (OLP) (5)

\section{Clinical criteria}

- Presence of white papule, reticular, annular plaque type lesions, gray white lines radiating from the papules.

- Presence of a lace like network of slightly raised gray white lines (reticular pattern).

- Presence of atrophic lesions with or without erosion, may also bullae.

\section{Histopathological criteria}

- Presence of thickened ortho or parakeratinized layer in sites with normally keratinized, and if site normally nonkeratinized this layer may be very thin.

- Presence of Civatte bodies in basal layer, epithelium and superficial part of the connective tissue.

- Presence of a well-defined band like zone of cellular infiltration that is confined to the superficial part of the connective tissue, consisting mainly of lymphocytes.

- Signs of 'liquefaction degeneration' in the basal cell layer. 
Table II: Proposal for a set of modified WHO diagnostic criteria of oral lichen planus (OLP) and oral lichenoid lesions (OLL) (6)

\section{Clinical criteria}

- Presence of bilateral, more or less symmetrical lesions.

- Presence of a lace-like network of slightly raised gray-white lines (reticular pattern).

- Erosive, atrophic, bulbous and plaque-type lesions are only accepted as a subtype in the presence of reticular lesions elsewhere in the oral mucosa.

- In all other lesions that resemble OLP but do not complete the aforementioned criteria, the term 'clinically compatible with' should be used.

\section{Histopathological criteria}

- Presence of a well-defined band-like zone of cellular infiltration that is confined to the superficial part of the connective tissue, consisting mainly of lymphocytes.

- Signs of liquefaction degeneration in the basal cell layer.

- Absence of epithelial dysplasia.

- When the histopathological features are less obvious, the term 'histopathologically compatible with' should be used.

Final diagnosis OLP or OLL

To achieve the final diagnosis, clinical as well as histopathologic criteria should be included

- OLP - A diagnosis of OLP requires fulfillment of both clinical and histopathological criteria

- OLL - The term OLL will be used under the following conditions.

1. Clinically typical of OLP but histopathogically only "compatible with" OLP.

2. Histopathologically typical of OLP but clinically only "compatible with" OLP.

3. Clinically "compatible with" OLP and histopathologically "compatible with" OLP.

were selected based on the clinician agreement that the clinical picture was diagnostic of OLP and the remaining 10 cases were clinically diagnosed as OLL. These were included as group 1 cases. For group 1 cases, a detailed clinical examination of the patients was performed. All the procedures of biopsy were explained to the patient. After obtaining written consent from the patient, reticular areas of the lesion were selected as the most appropriate site of biopsy and biopsy tissue was obtained under local anesthesia in aseptic conditions. A $3 \mathrm{~mm}$ incisional biopsy was obtained. Biopsy specimens were preserved in $10 \%$ buffered formalin solution, processed and paraffin embedded. Four micrometer sections were prepared and stained with Hematoxylin and Eosin (H\&E).

Fifty retrospective cases were retrieved from the archives based on the histopathological diagnosis of OLP and were considered group 2 cases. For group 2 cases, paraffin blocks of OLP were retrieved and sections of four micrometer were prepared. Sections were stained with routine H\&E stains. For these cases, clinical data was noted from the previous case history records and compared with their respective clinical data.

In both the study groups, the reviewing pathologists were blinded to the clinical presentation and site of biopsy.
All 100 Group 1 and 2 slides were reviewed by the three different oral pathologists. All the three oral pathologists were given the same 50 prospective and 50 retrospective histopathological slides. Slides were evaluated based on the proposal for a set of modified WHO diagnostic criteria of OLP and OLL (6) (Table II).

The discrete (categorical) clinical and histopahological OLP findings were compared by the chi-square $\left(\chi^{2}\right)$ test. The unweighted Kappa statistics was used to assess interobserver agreement. A two-sided $\mathrm{p}$ value less than $0.05(\mathrm{p}<0.05)$ was considered statistically significant.

\section{RESULTS}

Prospective findings: The inter-observer agreement of clinical and histopathological diagnosis of OLP among three observers was analyzed by using Kappa statistics and summarized in Table III. The Kappa statistics revealed "good" to "very good" agreement for both clinical and histopathological findings between the observers and agreement was higher in clinical findings than the histopathological findings.

The frequency distributions of prospective OLP findings (true/compatible) of both clinical and histological diagnoses are summarized in Table IV. In clinical diagnosis, there were $40(80.0 \%)$ true cases and $10(20.0 \%)$ compatible cases. 
Table III: Inter-observer agreement of prospective clinical and histopathological diagnosis of oral lichen planus using Kappa statistics

\begin{tabular}{|l|c|c|c|c|}
\hline \multirow{2}{*}{$\begin{array}{l}\text { Inter-observer } \\
\text { agreement }\end{array}$} & \multicolumn{2}{|c|}{ Clinical (n=50) } & \multicolumn{2}{c|}{ Histopathological (n=50) } \\
\cline { 2 - 5 } & Kappa statistics (к) & Strength of agreement & Kappa statistics (к) & Strength of agreement \\
\hline $\begin{array}{l}\text { Observer 1 vs. } \\
\text { Observer 2 }\end{array}$ & 0.85 & Very good & 0.78 & Good \\
\hline $\begin{array}{l}\text { Observer 1 vs. } \\
\text { Observer 3 }\end{array}$ & 0.89 & Very good & 0.84 & Gery good \\
\hline $\begin{array}{l}\text { Observer 2 vs. } \\
\text { Observer 3 }\end{array}$ & 0.79 & Good & 0.76 & Good \\
\hline
\end{tabular}

Table IV: Comparison of prospective clinical and histopathological diagnosis of oral lichen planus (OLP) using the chi-square test

\begin{tabular}{|l|c|c|c|c|}
\hline OLP findings & Clinical $(\mathbf{n}=\mathbf{5 0}) \mathbf{( \% )}$ & Histopathological $(\mathbf{n}=\mathbf{5 0}) \mathbf{( \% )}$ & $\chi^{\mathbf{2}}$ value (DF=1) & p value \\
\hline True & $40(80.0)$ & $19(38.0)$ & \multirow{2}{*}{18.23} & $<0.001$ \\
\hline Compatible & $10(20.0)$ & $31(62.0)$ & & \multirow{2}{*}{. } \\
\hline
\end{tabular}

In contrast, in histological findings, there were 19(38.0\%) true OLP cases, $8(16.0 \%)$ cases were compatible, $11(22.0 \%)$ OLD and 12(24.0\%) were diagnosed as others. Comparing the clinico-pathological diagnosis (true/compatible), the $\chi^{2}$ test reveled significantly different OLP findings between the two groups (true/compatible: $80.0 \% / 20.0 \%$ vs. $38.0 \% / 62.0 \%$, $\left.\chi^{2}=18.23, \mathrm{p}<0.001\right)$. In other words, regarding the findings for true OLP cases, the sensitivity of the clinical diagnosis was higher than the histopathological diagnosis $(80.0 \%$ vs. $38.0 \%$ ) while for compatible cases the sensitivity of the histopathological diagnosis was higher than the clinical diagnosis (20.0\% vs. $62.0 \%)$.
Retrospective findings: The inter-observer agreement of clinical and histopathological diagnosis of OLP among three observers were analyzed by using Kappa statistics and summarized in Table V. The Kappa statistics revealed "good" to "very good" agreement for both clinical and histopathological findings between the observers and agreement was higher in histopathological findings than clinical findings.

The frequency distributions of retrospective OLP findings (true/compatible) of both clinical and histological diagnosis are summarized in Table VI. Clinical diagnosis revealed 27

Table V: Inter-observer agreement of retrospective clinical and histopathological diagnosis of oral lichen planus using Kappa statistics

\begin{tabular}{|c|c|c|c|c|}
\hline \multirow{2}{*}{$\begin{array}{l}\text { Inter-observer } \\
\text { agreement }\end{array}$} & \multicolumn{2}{|c|}{ Clinical $(n=50)$} & \multicolumn{2}{|c|}{ Histopathological $(n=50)$} \\
\hline & Kappa statistics (к) & Strength of agreement & Kappa statistics (к) & Strength of agreements \\
\hline $\begin{array}{l}\text { Observer } 1 \text { vs. } \\
\text { Observer } 2\end{array}$ & 0.79 & Good & 0.83 & Very good \\
\hline $\begin{array}{l}\text { Observer } 1 \text { vs. } \\
\text { Observer } 3\end{array}$ & 0.81 & Very good & 0.86 & Very good \\
\hline $\begin{array}{l}\text { Observer } 2 \text { vs. } \\
\text { Observer } 3\end{array}$ & 0.75 & Good & 0.80 & Good \\
\hline
\end{tabular}

Table VI: Comparison of retrospective clinical and histopathological diagnosis of oral lichen planus (OLP) using the chi-square test

\begin{tabular}{|l|c|c|c|c|}
\hline OLP findings & Clinical $(\mathbf{n}=\mathbf{5 0})(\mathbf{\%})$ & Histopathological $(\mathbf{n}=\mathbf{5 0})(\mathbf{\%})$ & $\chi^{\mathbf{2}}$ value $(\mathbf{D F}=\mathbf{1})$ & p value \\
\hline True & $27(54.0)$ & $27(54.0)$ & \multirow{2}{*}{0.00} & \multirow{2}{*}{1.000} \\
\hline Compatible & $23(46.0)$ & $23(46.0)$ & & \\
\hline
\end{tabular}


(54.0\%) true OLP and $23(46.0 \%)$ compatible cases. The histopathological diagnosis also showed similar positive findings for true (54.0\%) and compatible (46.0\%) OLP cases. Thus, both clinical and histopathological diagnosis accounted for $54.0 \%$ moderate sensitivity for true OLP and $46.0 \%$ mild sensitivity for compatible OLP cases.

\section{DISCUSSION}

Clinical observations of the present study were similar to the previous published data except the gender distribution, in which the present study exhibited male predominance. However, a few surveys have also suggested male predominance. Other clinical features are similar to the previous studies, which include the common age group involved by the lesion being the third and fifth decades of life, involvement of bilateral buccal mucosa with a reticular pattern and being more symptomatic in erosive/ulcerative forms. OLP in children is uncommon and in our study it was observed in one case, showing a bilateral reticular pattern. Early diagnosis and treatment is essential in children to relieve the symptoms $(9,10)$.

In group 1, inter-observer agreement in the final diagnosis appears to be "good" to "very good" but correlation of the clinico-pathological diagnosis resulted in "mild" sensitivity of $38 \%$. Out of $40(80 \%)$ cases in which all clinicians agreed about the clinical diagnosis of OLP, only 19 (38\%) cases were histopathologically diagnosed as OLP. This assessment indicates that histopathological confirmation of clinical cases is mandatory for the final diagnosis of true OLP. Similarly in group 2, observer variability was found to be "good" to "very good" but correlation of the clinico-pathological diagnosis appear to be "moderate" sensitivity accounting for 54\%. Out of 50 (100\%) cases, in which all pathologists agreed about the diagnosis of OLP, only 27 (54\%) cases turned out to be clinically true OLP. From the observation of both the study groups, the clinico-pathological similarity between different OLL is evident. Hence we observed that factors contributing for lack of correlation are the inherent nature of OLP and OLL that shows overlapping clinico-pathological features. It is therefore mandatory for the clinician and pathologist to be aware of the clinico-pathological patterns of OLL.

In group 1 and 2, $8(16 \%)$ and $23(46 \%)$ cases were finally diagnosed as OLL. These lesions fail to show strict clinical and histopathological features proposed by modified WHO criterion for OLP. In group 1, cases revealed histopathological features such as extension of inflammatory cells in the deeper stroma, mixed population of inflammatory component, absence of basal cell liquefaction, perivascular cuffing of inflammatory cells and rarely aggregation of inflammatory cells in the form of lymphoid follicles. In group 2, cases were unilateral, solitary and sometimes erythematous without a characteristic reticular pattern. Our observations match with the previous published articles that have mentioned similar clinical and histopathological features of OLL (11). Segregation of OLP and OLL by clinico pathological assessment is a must, as some OLL cases such as GVHRs and OLL of unknown origin have high propensity for malignant transformation $(12,13)$.

The appropriate selection of the biopsy site has a vital role in the accurate diagnosis of OLP. Previous studies have reported that reticular lesions were histopathologically diagnosed as OLP much more consistently than erythematous and erosive lesions $(9,10)$. Our observations were in agreement with these findings, as the biopsy was taken from the reticular area of the lesion in 13 (26\%) out of $19(38 \%)$ cases diagnosed as true OLP. In a few instances the histopathological features may not be diagnostic as OLP evolves through a cycle of exacerbation and quiescence. Biopsy in any condition helps to differentiate whether the lesion is of inflammatory origin or consists of underlying atypical features in the epithelium. It is always possible that more than one disease process can coexist together. Hence it is prudent to take multiple biopsies. If multiple biopsies are not possible, biopsy of the cancer prone site is more precise (14).

In the present study, 11 (22\%) cases in group 1 exhibited epithelial dysplasia along with the characteristic lichenoid infiltrate in the juxta epithelium. These lesions are histopathologically named oral lichenoid dysplasia (OLD). Our results emphasize the significance of assessing the epithelial maturation and cytomorphology in any OLP case as many studies have documented that there are serious flaws in the initial diagnosis of OLP (12-15) only based on the similarly appearing lichenoid infiltrate in the stroma to the extent of ignoring atypical features in the epithelium. OLP and OLD share essentially no pathogenetic relationship but their similarity is the presence of lichenoid inflammatory infiltrate. In OLP, the lichenoid infiltrate represents cell-mediated immune response provoked by different antigens, whereas in OLD, the lichenoid infiltrate represents the immune surveillance mechanism against atypical epithelial cells (4). Out of 11 (22\%) cases, $8(16 \%)$ cases were diagnosed as OLD from clinically true OLP. Only $4(8 \%)$ cases were associated with habits and $5(10 \%)$ cases were erosive/ulcerative forms. Hence our observations were not in accordance with the previous 
studies that have suggested these lesions are predominantly solitary erosive areas occurring on a cancer prone site and associated with habits $(12,14,16)$. None of the OLP cases in the study were associated with Candida albicans, as it was hypothesized that candida can form carcinogenic $\mathrm{N}$-nitrosobenzylmethylamine that is associated with malignant transformation of OLP (10-16).

In conclusion, the results of the present study show a lack of clinico-pathological correlation in the diagnostic assessment of OLP. To confirm the clinical diagnosis of OLP, histopathological assessment has to be performed and the final diagnosis has to be achieved only after the correlation of clinical and histopathological diagnosis. Assessment of OLP and OLL based on modified WHO criteria displayed a significant role in the accurate differentiation of OLP from OLL and OLD.

\section{ACKNOWLEDGMENT}

The authors thank Mr. M.P.S. Negi, Statistician, Institute for Data Computing and Training (I.D.C.T.), Lucknow, for providing valuable assistance in data analysis.

\section{REFERENCES}

1. Scully C, Beyli M, Ferreiro MC, Ficarra G, Gill Y, Griffiths M, Holmstrup P, Mutlu S, Porter S, Wray D. Update on oral lichen planus: Etiopathogenesis and Management. Crit Rev Oral Biol Med. 1998;9:86-122.

2. Moncarz V, Ulmansky M, Lustmann J. Lichen planus: Exploring its malignant potential. J Am Dent Assoc. 1993;124:102-8.

3. Eisen D, Carrozzo M, Bagan Sebastian JV, Thongprasom K. Oral lichen planus: Clinical features and management. Oral Dis. 2005;11:338-49.

4. Eisenberg E. Clinico pathologic patterns of oral lichenoid lesions. OMFS Clin North Am. 1994;6:445-61.

5. Kramer IR, Lucas RB, Pindborg JJ, Sobin LH. Definition of leukoplakia and related lesions: An aid to studies on oral precancer. Oral Surg Oral Med Oral Pathol. 1978;46:518-39.
6. Van der Meij EH, van der Waal I. Lack of clinico pathologic correlation in the diagnosis of oral lichen planus based on the presently available diagnostic criteria and suggestion for modification. J Oral Pathol Med. 2003;32:507-12.

7. van der Meij EH, Reibel J, Slootweg PJ, van der Wal JE, de Jong WF, van der Waal I. Interobserver and intraobserver variability in the histologic assessment of oral lichen planus. J Oral Pathol Med. 1999;28:274-7.

8. van der Meij EH, Schepman KP, Plonait DR, Axéll T, van der Waal I. Interobserver and intraobserver variability in the clinical assessment of oral lichen planus. J Oral Pathol Med. 2002;31:95-8.

9. Xue JL, Fan MW, Wang SZ, Chen XM, Li Y, Wang L. A clinical study of 674 patients with oral lichen planus in China. J Oral Pathol Med. 2005;34:467-72.

10. Eisen D. The Clinical features, malignant potential and systemic association of oral lichen planus: A study of 723 patients. J Am Acad Dermatol. 2002;46:207-14.

11. Farthing PM, Speight PM. Problems and pitfalls in oral mucosal pathology. Cur Diag Pathol. 2006;12:66-74.

12. Lodi G, Scully C, Carrozzo M, Griffiths M, Sugerman PB, Thongprasom K. Current controversies in oral lichen planus: Report of an international consensus meeting. Part 2. Clinical management and malignant transformation. Oral Surg Oral Med Oral Pathol Oral Radiol Endod. 2005;100:164-78.

13. Gonzalez-Molis MA, Scully C, Gil-Montoya JA. Oral lichen planus: Controversies surrounding malignant transformation. Oral Dis. 2008;14:229-43.

14. Eisenberg E. Oral lichen planus: A benign lesion. J Oral Maxillofacial Surg. 2000; 58:1278-85.

15. Van der Waal I. Oral lichen planus and oral lichenoid lesions; A critical appraisal with emphasis on the diagnostic aspects. Med Oral Patol Oral Cir Bucal. 2009;14:E310-4.

16. Van der Meij EH, Schepman KP, van der Waal I. The possible premalignant character of oral lichen planus and oral lichenoid lesions. A prospective study. Oral Surg Oral Med Oral Pathol Oral Radiol Endod. 2003;96: 164-71. 